\title{
FINANCIAL CAPABILITY AMONG LOW-INCOME HOUSEHOLDS IN RURAL PARTS OF POLAND
}

This paper examines low-income households' financial capability by looking at their financial literacy, financial behaviour as well as financial inclusion. Using the data from micro-study, the author proves that even though financial literacy among low-income households is very low, most financial behaviour (especially the basic ones like managing a financial budget) are rather high. It seems that being financially illiterate does not stop lowincome households from being financially capable, which might be mainly connected with some social and environmental factors that shape their capability and help low-income members of households to find some other ways of achieving satisfactory level of financial behaviour than just through increasing financial literacy. Moreover, having little money forces low-income households to become very careful financial decision-makers. Additionally, the multivariate analysis has shown that being financially literate (especially risk and debt literate) and being financially included are key latent factors in understanding financial capability among low-income households from rural regions of Poland. These two factors also play a significant role in understanding the adaptation to low-income among the polled households (measured by the marginal effects of pseudo- $\mathrm{R}^{2}$ ratio in logit model).

Keywords: financial capability, financial literacy, personal finance, low-income, financial inclusion, capability approach, poverty, rural regions

JEL Classifications: R20, D12, D14, I25, I32

DOI: $10.15611 /$ aoe.2019.2.04

\section{INTRODUCTION}

All around the world, most members and their households are constantly worried about how to pay the bills and ongoing expenses. Generally, the lower the level of income the higher the probability of financial insecurity and financial distress (Dubois and Rousseau 2008; Collins et al. 2009; Lusardi et al. 2011; Morduch and Schneider 2017). This financial fragility of low-income households is closely related to the higher risk associated with daily financial decisions, which results in a narrower margin for error (Bertrand et al. 2004: 419) as well as the frequency and severity of the experienced financial shocks (Banerjee and Duflo 2011: 134). Therefore,

\footnotetext{
* Department of Economic Policy, University of Rzeszów.
} 
growing financial insecurity is a product of inability and the lack of opportunities to transform this small income and social benefits into a valuable financial behaviour. To protect low-income households from financial insecurity, stress and shocks, financial institutions have to help people in developing and delivering financial knowledge, skills, abilities and opportunities which in primis will help these households to better manage their finance and better control their lives (Ravallion 2001, 2014; Sherraden and Grinstein-Weiss 2015).

In the academic world ${ }^{1}$, these endogenous (so-called abilities) and exogenous (so-called opportunities) determinants of financial choice are often defined as financial capability ${ }^{2}$. They are described as both the internal capability to act, defined as knowledge, skills and abilities, as well as the external opportunity to act, defined as financial potential, capacity and access (Arrowsmith and Pignal 2010; Hoelzl and Kapteyn 2011; Sherraden 2013; Kempson et al. 2013). Therefore, financial capability refer to both the opportunity and the ability to function. Limited valuable financial opportunity (a narrow set of financial choices among the functions) can lead to financial capability deprivation (inability to function in a responsible and ethical way).

Compared to previous research, this study contributes to financial capability research in three aspects. First, in this study the author includes among the measures of financial capability not only the extensively used financial literacy and financial behaviour (both objective and subjective) but also financial inclusion (Atkinson et al. 2006, Taylor 2011; Kempson et al. 2013). As shown in the growing body of evidence, the way low-income households deal with financial shocks by using financial products is highly important in both cases: financial capability protection (Dubois and Rousseau 2008; Lusardi et al. 2011; Stumm et al. 2013) and the effectiveness of transformation of these capabilities into valuable financial

\footnotetext{
${ }^{1}$ The growing interest in financial capability studies is demonstrated by the fact that two prestigious and internationally acknowledged academic journals (Journal of Economic Psychology Vol. 32, The Journal of Consumer Affairs Vol. 49) devoted a whole special issue to the topic.

${ }^{2}$ Some literature refer only to financial literacy, however, because of the fact that "Financial capability is considered a broader concept that also highlights action and behavior of the individual, and the relevance of outside institutions and regulations" (Hoelzl and Kapteyn 2011: 543; Sherraden and Grinstein-Weiss 2015) the author uses only the term 'financial capability' to improve the transparency of the discussion, in the awareness of limitations of this approach.
} 
behaviour (Sen 1999, 2009, Robeyns 2005, 2017). Second, this study uses a unique micro database of households who are cumulatively deprived in terms of income ${ }^{3}$ (Bradshaw and Finch 2003, Wolff and De-Shalit 2008). The usage of micro studies in poverty analysis is highly appreciated by researchers. As quoted by Ravallion (2001:1813), "more micro, countryspecific research on the factors determining why some poor people are able to take up the opportunities afforded by an expanding economy while others are not". Third, this study looks at financial capability from the perspective of post-communist countries. Since even well-educated wealthy households from rich countries are not able to make responsible financial choices, then prima facie the uneducated, low-income households from rural regions of post-communist countries, who have not yet or incidentally used financial services, are doomed to failure (Bogacka-Kisiel (ed.) 2012; Szopa (ed.) 2012). Panek (2011: 201-5) showed that the income poverty as a result of high and unexpected debt exposure is the highest in post-communist countries from among the EU members. The main reason for such a deprivation in post-communist countries is that a centrally planned system did not require establishing the financial capability (both internal and external), consequently had not created the right social, institutional environment which would have helped in taking wise and responsible financial decisions (allow the right financial behaviour). Only a limited group of households managed to adapt to the new reality, whereas a great number of them failed (Szopa (ed.) 2012: 9). Frieske (1996: 237) said, "not the lack of money but the lack of access to knowledge and capabilities is a fundament of poverty in Poland". This kind of deprivation may increase vulnerability, finally resulting in the increase of poverty risk or the inability to escape from the poverty trap.

The article is organized as follows: some issues concerning financial capability conceptualization and measurement will be discussed in Section 2, the data and methodology will be briefly discussed in Section 3. Section 4 is devoted to the measurement of financial capability using factor analysis and logistic regression. Section 5 will conclude and summarize the conceptual and operational findings.

\footnotetext{
${ }^{3}$ In this article the author uses low-income as a simple measure of poverty. The evolution of methods indicating poverty by using low-income is comprehensively discussed by the Polish researchers; see: Golinowska (ed.) 1996; Panek et al. 1999, Kot et al. 2004, Panek (ed.) 2007, Panek 2005, 2011. The limitation of these methods are discussed in: Golinowska (ed.) 2005; Sen 1997, 1999, Atkinson 2003; Fleurbaey 2006; Topińska (ed.) 2008; Nolan and Whelan 2010; Panek 2011; Alkire et al. 2015 inter alia.
} 


\section{CONCEPTUALIZATION OF FINANCIAL CAPABILITY - A CRITICAL REVIEW}

In most cases the research on financial capability is interdisciplinary. The assessment of multidimensional poverty focuses on searching for the main poverty determinants (mainly capability deprivation), the research on behavioural economics explores how individuals make financial choices (Hoelzl and Kapteyn 2011; Anand and Lea 2011), whereas customer studies answer the question of how responsible their financial behaviour is and what factors shape this behaviour (Xiao et al. 2014; 2015; Xiao and O'Neill 2016). This gives rise to difficulties with defining financial capability, due to the fine distinction between the terms: financial literacy, financial behaviour, financial choice, financial attitude and financial capability ${ }^{4}$. Moreover, it creates a number of methodological questions. Is it possible to assess something that may not be transferred into the achieved functions? (we have choice options but we do not exercise them, we are not aware of the choice options, among others) - especially in view of the fact that research methods of behavioural economics are based on experimental analysis of financial choice and decisions focusing mainly on decision biases and the process of choice (Kempson et al. 2013: XIII; Sen 1984: 335). Hence, if behavioural economics is the starting point here, financial capability are actually the analysis of financial decision process, which are not financial capability per se (Robeyns 2017: 83). On the other hand, in customer studies the measurement of financial capability cover in most cases surveys constructed to measure financial functioning (defined as financial behaviour), but not capability in Sen's view of Capability Approach (Sen 1982: 31, 1984: 334).

Another disputable issue is the fact that recently attention has shifted from financial literacy towards financial capability (Kempson 2009, Zdanowska 2012; Kuchciak et al. 2013; Sherraden 2013, Świecka (ed.) 2014; Xiao and O'Neill 2016, Sherraden and Grinstein-Weiss 2015). The lack of distinction between these terms, and the fact that they are used interchangeably has resulted for example in defining the term 'financial literacy' in such a way that it combines lots of concepts. Financial literacy has been defined as "a combination of awareness, knowledge, skills, attitude and behaviour necessary to make sound financial decisions and ultimately

\footnotetext{
${ }^{4}$ In Poland an interesting alternative and widely used concept which describes the term financial capability is the concept "financial awareness"(Flejterski 2007: 100; Iwanicz-Drozdowska (ed.) 2011: 9, 15-16, 18). This idea derives mainly from the work of Polish sociologists and psychologists from the 1970s.
} 
achieve individual financial wellbeing. (...) Financial literacy is more than just knowledge; it also includes attitudes, behaviour and skills. It stresses the importance of decision making - applying knowledge and skills to real life processes - and it indicates that the impact should be improved financial wellbeing" (Atkinson and Messy 2012: 4). Financial literacy represents knowledge and the skills people have and use, but in fact, it has only an instrumental value. It may still be an important personal conversion factor (in Sen's terminology of Capability Approach). This was pointed out by Lusardi (2011: 1), who stated that "financial literacy is an important tool for making financial decisions, it can provide only limited descriptions of how capable members of households are and of the ways households make financial decisions".

It is worth mentioning that most analyzed definitions of financial capability (also in Poland) are drawn mainly from financial literacy and narrowly defined as the internal capability to act or ability to act (see points 1 to 4,7 to 8 in Table 1 ).

There are two main conclusions from the critical review in Table 1. First, the most frequently quoted definition of financial capability is the one proposed by Kempson et al. (2005: 14), which indicates three coexisting dimensions. The first two (levels 1 and 2) refer to financial literacy, whereas by taking into account the third dimension, among others financial responsibility, one extends the definition to financial capability. The abovementioned definition suggested by Kempson et al. (2005) comes from an FSA elaboration and was used in papers written by Lusardi, Arrowsmith and Pignal, H.M. Treasury, and recommended by the European Parliament and the European Commission. Second, the analysis presented in Table 1 shows that the categorization into financial literacy (levels 1 and 2 in Table 1) and financial capability (level 3 in Table 1) adopted by other authors, is in line with most financial capability research. Moreover, it allows responsibility as a result of increasing financial knowledge, financial literacy and eventually financial capability, especially when dealing with financial institutions (Sherraden 2013; Sherraden and Grinstein-Weiss 2015).

Regardless of the starting point, either the Capability Approach, customer studies or behavioural economics, one is able to find a unique compromise closely related components, financial literacy as a part of individual conversion factors in Sen's terminology, financial decisions as a part of constrained choice, financial behaviour as achievable or achieved functionalities and financial capability as a part of capability set (Nussbaum 2011: 21-24, Sen 1985: 7-10, 1997: 199-203, Robeyns 2017: 80-85). 
Table 1

Conceptualizing financial capabilities - critical review

\begin{tabular}{|c|c|c|c|}
\hline Authors & $\begin{array}{c}\text { Level } 1 \\
\text { Financial knowledge }\end{array}$ & $\begin{array}{c}\text { Level } 2 \\
\text { Financial literacy }\end{array}$ & $\begin{array}{c}\text { Level 3 } \\
\text { Financial capabilities }\end{array}$ \\
\hline $\begin{array}{l}\text { - FSA and BSA } \\
\text { 2002: } 4 \\
\text { - Kempson et } \\
\text { al. } 2005: 14 \\
\text { - Arrowsmith } \\
\text { and Pignal } \\
\text { 2010:10 } \\
\text { - European } \\
\text { Parliament } \\
\text { 2008 } \\
\text { - Świecka (ed.) } \\
\text { 2014 } \\
\text { - Zdanowska } \\
\text { 2012 } \\
\text { - Kuchciak et } \\
\text { al. } 2012 \\
\end{array}$ & $\begin{array}{l}\text { Financial knowledge } \\
\text { and understanding. } \\
\text { This is the ability to } \\
\text { make sense of and } \\
\text { manipulate money in } \\
\text { its different forms, uses } \\
\text { and functions }\end{array}$ & $\begin{array}{l}\text { Financial skills and } \\
\text { competences. This is } \\
\text { the ability to apply } \\
\text { knowledge and } \\
\text { understanding across } \\
\text { a range of contexts } \\
\text { including both } \\
\text { predictable and } \\
\text { unexpected situations }\end{array}$ & $\begin{array}{l}\text { Financial responsibility (as } \\
\text { confidence and attitudes). This is } \\
\text { the ability to appreciate both the } \\
\text { wider impact on family and the } \\
\text { broader community. Financial } \\
\text { responsibility enables people to } \\
\text { understand and appreciate their } \\
\text { rights and responsibilities within } \\
\text { Managing Money, Planning } \\
\text { Ahead, Choosing Products, Staying } \\
\text { Informed dimension }\end{array}$ \\
\hline $\begin{array}{l}\text { - Kempson et } \\
\text { al. 2013: } 15- \\
16\end{array}$ & \multicolumn{2}{|c|}{$\begin{array}{l}\text { Internal capacity. To manage financial } \\
\text { resources is measured by assessing financial } \\
\text { knowledge (literacy), attitudes (observable } \\
\text { psychological factors) and cognitive skills }\end{array}$} & $\begin{array}{l}\text { Financial behaviour. Offers an } \\
\text { important avenue for understanding } \\
\text { the interaction between the internal } \\
\text { capacities described above } \\
\text { (knowledge, attitude, skills) and } \\
\text { external socioeconomic } \\
\text { environmental conditions }\end{array}$ \\
\hline $\begin{array}{l}\text { - Sherraden } \\
\text { 2013,p.3, } \\
\text { Xiao and } \\
\text { O’Neill 2016: } \\
712\end{array}$ & \multicolumn{2}{|c|}{$\begin{array}{l}\text { Ability to act. Including knowledge, skills, } \\
\text { confidence, and motivation }\end{array}$} & $\begin{array}{l}\text { Opportunity to act. Through } \\
\text { access to beneficial financial } \\
\text { products and institutions }\end{array}$ \\
\hline $\begin{array}{l}\text { Hoelzl, } \\
\text { Kapteyn } \\
\text { 2011:543 }\end{array}$ & \multicolumn{2}{|c|}{$\begin{array}{l}\text { Financial literacy. Mainly focuses on the } \\
\text { understanding of economic and financial } \\
\text { concepts and knowledge about financial } \\
\text { instruments }\end{array}$} & $\begin{array}{l}\text { Confidence and attitudes. } \\
\text { Highlights action and behaviour of } \\
\text { the individual, and the relevance of } \\
\text { outside institutions and regulations }\end{array}$ \\
\hline $\begin{array}{l}\text { - HM Treasury } \\
\text { 2007:19 }\end{array}$ & \multicolumn{2}{|c|}{$\begin{array}{l}\text { Financial knowledge and skills. To } \\
\text { understand their own financial circumstances. }\end{array}$} & $\begin{array}{l}\text { Motivation to take action. } \\
\text { Planning ahead, find and use } \\
\text { information, know when to seek } \\
\text { advice and can understand and act } \\
\text { on this advice, leading to greater } \\
\text { participation in the financial } \\
\text { services market }\end{array}$ \\
\hline $\begin{array}{l}\text { - Lusardi } \\
\text { 2011:1, } \\
\text { Lusardi 2008: } \\
2,5\end{array}$ & \multicolumn{2}{|c|}{$\begin{array}{l}\text { Financial literacy. Knowledge about the } \\
\text { fundamental financial concepts working of } \\
\text { interest rates, the effects of inflation, and the } \\
\text { concept of risk diversification as well as } \\
\text { understanding the relationship between risk and } \\
\text { return; how bonds, stocks, and mutual funds } \\
\text { work; and basic asset pricing. }\end{array}$} & $\begin{array}{l}\text { Financial capability. How well } \\
\text { people make ends meet plan ahead, } \\
\text { choose and manage financial } \\
\text { products. }\end{array}$ \\
\hline
\end{tabular}

Source: own review. 
To sum up, financial capability have already taken an important place in the discussion on personal finance and customer studies. Unfortunately, there have been only limited attempts to define financial capability within the Capability Approach (especially Sen's framework). This is of great importance because the lack of such capability may expose at risk different capability sets or prevent people from sustaining or achieving them (for example financing education, treatment of chronic diseases, and active participation in socio-cultural life). Moreover in extreme situations it may even pose danger for the basic functioning (for example, it may result in suicide), when a failed financial decision leads to a drastic reduction of quality of life or the social exclusion of some household members or even an entire household (Sen 1999: 39). Hence, the lack of financial capability may function as mentioned by Kot (2004: 36) as "a destructive axiological dimension".

\section{DATA AND METHODOLOGY}

The process of sample selection was aimed at identifying households which are cumulatively deprived in terms of low-income (Bradshaw and Finch 2003, Wolff and De-Shalit 2008). However, the author defines households as cumulatively deprived when they are situated in rural and peripheral regions - consequently they are at risk of exclusion from financial and labour market, as well as social relations, health and education services; are objectively poor in terms of low-income - live under the social subsistence level; and are subjectively poor - declare that their financial situation is difficult (Bradshaw and Finch 2003: 514).

Moreover, rural areas in post-communist countries, particularly the peripheral ones, might be historically and institutionally "handicapped" in terms of low financial capability due to:

- still existing distinctive social and cultural specificity (Bukraba-Rylska 2013),

- the widest scope of socioeconomic transformations in the way they function, in comparison to other types of households (Wilkin (ed.) 2010),

- distinctively more constraints in access to education, labour and financial market as well as social services (Jarosz (ed.) 2008).

Subsequently in these regions these three factors are overlapping (so-called structural constraints), i.e. financial factors (education is too 
expensive), social and psychological factors (self-exclusion as a result of the lack of motivation) and institutional factors (low quality of obligatory education), which may widen the financial capability gap between rural and urban areas.

Thus, 52 small rural regions (NUTS 5 level according to Eurostat) were selected from the Podkarpacie voivodeship to conduct the micro-study. The author selected a very homogenous population sub-group within a given social environment. A sample size of 384 random households was determined with respect to a 5 percentage point error and 0.95 confidence interval. The effective sample size encompassed 296 households, which gives a 5.53 percentage point error. The author used a random location sample, selecting locations with probability proportional to size from a listing of small rural areas. The interview was conducted by a local person who has access to the local community, and what is more, is a professional interviewer under the auspices of the Statistical Office in Rzeszów. A personal structured interview (the PAPI method) was conducted with the head of the family responsible for managing the financial budget. Each interview lasted for approximately 90 minutes. From random sample households (296 households) only the ones living at or under the social subsistence level were chosen (194 households) for statistical analysis. The selected sample was then divided into two other subgroups: 109 subjectively poor households, suffering from deprivation, and 85 subjectively non-poor households, adapted to low-income (see also: Rószkiewicz 2014: 603). According to international financial capability frameworks, when the coherent sample with similar socio-economic characteristics is selected, an average number of 300 households might be enough (Kempson 2013: 18).

The sample is dominated by women (134), comprising 69.07 percent of the sample. In the preliminary studies, during the in-depth individual interviews and focus group interviews, most of the women claimed "My husband is responsible for bringing money home and I am responsible for them wisely". The median age is between 35 and 46 years (the mode is the same), the median education level is secondary general or vocational (the mode is the same), and the median number of household members is four (the mode is the same). Moreover, in every second household (56.24 percent) there is at least one unemployed member. The majority of those polled are local people who grew up and have lived until adolescence in this particular rural region or the nearest small town (188), comprising 96.91 percent of the sample. 
Table 2

Demographic characteristics of respondents

\begin{tabular}{l|c|c|c|c|c|c}
\hline & $\mathbf{N}$ & Average & Median & Min & Max & S.D. \\
\hline Location (poor region) & 194 & 3.76 & 4 & 1 & 4 & 0.52 \\
\hline Gender (women) & 194 & 0.69 & 1 & 0 & 1 & 0.46 \\
\hline Education (secondary general or vocational) & 194 & 6.4 & 7 & 1 & 8 & 1.58 \\
\hline Age (35-46) & 194 & 3.46 & 3 & 1 & 6 & 1.25 \\
\hline Marital status (married) & 194 & 2.02 & 2 & 1 & 5 & 0.76 \\
\hline Number of household members (4) & 194 & 3.96 & 4 & 1 & 10 & 1.46 \\
\hline
\end{tabular}

Source: own study.

The final questionnaire (after preliminary study corrections) included 87 main questions separated into four parts.

- 12 demographic and economic variables, including age, sex, education level, number of household members, employment status, etc.,

- 43 household financial behaviour variables, including dealing with financial shocks, unexpected expenditures, financial complaints, budget, making ends meet, planning ahead, choosing and managing financial products, etc.,

- 12 behavioural and attitudinal variables, including long-term planning attitude, consumerism, materialism, subjective well-being, trust, altruism level, money attitude, lacus of control, time preference, financial aspiration level, risk perception, etc.,

- 20 financial literacy variables, including self-perception of financial literacy, objective measure of self-control, numeracy, risk, debt and investment literacy, etc.

The main aim was to integrate informational basis for financial capability, including financial literacy, financial behaviour, financial attitude, and financial inclusion variables on the low-income households, which are generally defragmented in different panel studies or largely omitted. Questions from the above-mentioned questionnaires were also adopted to Polish conditions in the preliminary research using the method of back-translation. Some of them were reformulated after the in-depth individual interviews with social experts and focus group interviews with educators from those regions. 


\section{RESULTS AND DISCUSSION}

First, descriptive statistics were used to assess four dimensions of financial capability among low-income households. Second, multivariate techniques, including factor analysis and logistic regression, were applied to better understand the correlation between low-income and financial capability.

\subsection{Descriptive statistics}

First of all, the author assessed the level of financial literacy. The results show that there is a great number of low-income members of households (the median score is 2 for 3 ) but they are necessarily risk and debt illiterate (the median score is 0 for 3 and 1 for 4 ).

Table 3

Descriptive statistics for financial literacy variables

\begin{tabular}{l|c|c|c|c|c|c}
\hline & $\begin{array}{c}\text { Number } \\
\text { of questions }\end{array}$ & Average & Median & Min & Max & S.D. \\
\hline Numeracy & 3 & 1.47 & 2 & 0 & 3 & 1.03 \\
\hline Risk literacy & 3 & 0.64 & 0 & 0 & 3 & 0.88 \\
\hline Financial literacy & 4 & 1.88 & 2 & 0 & 4 & 1.21 \\
\hline Investment literacy & 5 & 1.71 & 2 & 0 & 5 & 1.39 \\
\hline Debt Literacy & 4 & 0.87 & 1 & 0 & 4 & 0.93 \\
\hline Self-Control Test & 3 & 0.85 & 1 & 0 & 3 & 0.71 \\
\hline
\end{tabular}

Source: own study.

Moreover, Frederick's self-control test score is also very low (the median score is 1 for 3 ). These two issues (lack of risk understanding as well as lack of self-control) together with short time preferences may have a "cumulative effect" and put their household's life at risk due to poor risk choice assessment and as a consequence of self-control and the use of high-cost loans (Pechmann et al. 2005; Bertrand et al. 2006; Lusardi and Tufano 2009; Lusardi et al. 2011; von Stumm et al. 2013). One could observe this phenomenon clearly during and shortly after the financial crises in several countries (Shiller 2012; Akerlof and Shiller 2015). What is more, using only a numeracy scale to assess the financial literacy might be inadequate due to different factors influencing the mean score. The Spearman correlation ratio between debt and risk literacy and other literacy scores is very low. 
Table 4

Correlations between financial literacy variables

\begin{tabular}{l|c|c|c|c}
\hline \multicolumn{1}{c|}{ Pair of items } & N & $\begin{array}{c}\text { Spearman's rank } \\
\text { correlation } \\
\text { coefficient: }\end{array}$ & T(N2) & Sig. \\
\hline Numeracy \& Risk literacy & 194 & 0.547 & 9.060 & 0.000 \\
\hline Numeracy \& Financial literacy & 194 & 0.409 & 6.219 & 0.000 \\
\hline Numeracy \& Investment literacy & 194 & 0.451 & 6.993 & 0.000 \\
\hline Numeracy \& Debt literacy & 194 & 0.406 & 6.148 & 0.000 \\
\hline Numeracy \& Self-control test & 194 & 0.390 & 5.873 & 0.000 \\
\hline Risk literacy \& Numeracy & 194 & 0.547 & 9.060 & 0.000 \\
\hline Risk literacy \& Financial literacy & 194 & 0.442 & 6.834 & 0.000 \\
\hline Risk Literacy \& Investment Literacy & 194 & 0.353 & 5.231 & 0.000 \\
\hline Risk literacy \& Debt literacy & 194 & 0.325 & 4.766 & 0.000 \\
\hline Risk literacy \& Self-control test & 194 & 0.346 & 5.104 & 0.000 \\
\hline Financial literacy \& Numeracy & 194 & 0.409 & 6.219 & 0.000 \\
\hline Financial literacy \& Risk literacy & 194 & 0.442 & 6.834 & 0.000 \\
\hline Financial literacy \& Investment literacy & 194 & 0.409 & 6.208 & 0.000 \\
\hline Financial literacy \& Debt literacy & 194 & 0.279 & 4.020 & 0.000 \\
\hline Financial literacy \& Self-control test & 194 & 0.200 & 2.830 & 0.005 \\
\hline Investment literacy \& Numeracy & 194 & 0.450 & 6.993 & 0.000 \\
\hline Investment literacy \& Risk literacy & 194 & 0.353 & 5.231 & 0.000 \\
\hline Investment literacy \& Financial literacy & 194 & 0.409 & 6.208 & 0.000 \\
\hline Investment literacy \& Debt literacy & 194 & 0.367 & 5.470 & 0.000 \\
\hline Investment literacy \& Self- control test & 194 & 0.289 & 4.191 & 0.000 \\
\hline Debt literacy \& Numeracy & 194 & 0.406 & 6.148 & 0.000 \\
\hline Debt literacy \& Risk literacy & 194 & 0.325 & 4.766 & 0.000 \\
\hline Debt literacy \& Financial literacy & 194 & 0.279 & 4.020 & 0.000 \\
\hline Debt literacy \& Investment literacy & 194 & 0.367 & 5.470 & 0.000 \\
\hline Debt literacy \& Self-control test & 194 & 0.206 & 2.922 & 0.004 \\
\hline
\end{tabular}

* significant at 5 percent level

Source: own study.

The highest but still rather weak correlation is between numeracy and risk literacy $(0.5472)$, which may prove that numeracy is a valuable but not sufficient prerequisite for risk literacy building (Cokely et al. 2012). Therefore, the results of the study prove what Gigerenzer (2015: 2) and his ABC Research Group in the Max Planck Institute have been trying to communicate for the last twenty years: "The problem is not simply individual stupidity, but the phenomenon of a risk-illiterate society (...). Without it [risk literacy: author's comment] you jeopardize your health and money, or may be manipulated into unrealistic fears and hopes" (see also: 
Gigerenzer and Hoffrage 1995; Gigerenzer and Edwards 2003; Gigerenzer 2004). To sum up, low-income households represent a very low level of financial literacy in general. However, they are not an exception but rather the rule in comparison to households from rich and developed regions (Atkinson et al. 2006; Lusardi 2008; Atkinson and Messy 2012). In fact, these households are generally aware of that, because only a few respondents were of the opinion that their financial literacy fell between high and very high (13, i.e. 6.7 percent of the sample). Secondly, the study covered an assessment of the level of a wide range of financial behaviour, which was performed by asking the head of household if or how they manage their budget, use savings and financial services. The majority of the poll (135, i.e. 78.04 percent of the sample) claimed that their ability to manage the household budget is between 'rather high' or 'very high' (with median value 'rather high'). The managing household budget skills are not reflected in their answer to the questions if they plan their household budget (62, i.e. 32 percent of the sample) and if they have savings (75, i.e. 38.66 percent of the sample).

Table 5

Descriptive statistics for selected financial capabilities variables

\begin{tabular}{l|c|c|c|c|c|c}
\hline & $\mathbf{N}$ & Average & Median & Min & Max & S.D. \\
\hline $\begin{array}{l}\text { Self-perception of household finance } \\
\text { management (6 mod.) }\end{array}$ & 173 & 3.98 & 4 & 1 & 6 & 0.97 \\
\hline Managing financial budget (4 mod.) & 194 & 3.46 & 4 & 1 & 4 & 0.80 \\
\hline Having savings (dichotomous) & 194 & 0.61 & 1 & 0 & 1 & 0.49 \\
\hline Having bank account (dichotomous) & 194 & 0.87 & 1 & 0 & 1 & 0.343 \\
\hline Active usage of bank account (5 mod.) & 167 & 1.62 & 1 & 0 & 4 & 1.19 \\
\hline $\begin{array}{l}\text { Type of payment methods for day-to-day } \\
\text { purchases (5 mod.) }\end{array}$ & 193 & 1.60 & 1 & 1 & 4 & 1.20 \\
\hline $\begin{array}{l}\text { Type of payment methods for ongoing } \\
\text { expenses (6 mod.) }\end{array}$ & 180 & 2.60 & 2 & 1 & 6 & 1.47 \\
\hline $\begin{array}{l}\text { Planning how much money to save and } \\
\text { spend (dichotomous) }\end{array}$ & 194 & 0.32 & 0 & 0 & 1 & 0.47 \\
\hline
\end{tabular}

Source: own study.

That means that they may overvalue their household budget skills or define them differently. Moreover, the majority of them are financially included (168, i.e. 86.6 percent of the sample). Nevertheless, most of them are underbanked (136, i.e. 81.43 percent of the subsample) and do not execute more than three transactions a week in their banking account. This 
reflects the way respondents pay for small daily purchases, which is mainly cash, (154, or 79.79 percent of the sample) as well as pay for bills, which is also mainly cash (108, or 60.0 percent of the sample) equally distributed between a bank branch (53 out of 180) and a post office (55 out of 180). What is even more striking is that none of the respondents has ever used credit cards, mobile payment or non-banking cards to pay for small daily purchases. This only proves the ongoing existence of a "cash cult" in postcommunist countries and "technology aversion" in rural, peripheral parts of Poland (Goszczyńska 2010; Maison 2013; World Bank 2014). For instance, the study shows that only a few households have ever used a savings account (39, i.e. 20.10 percent of the sample) and opened a deposit account (66, i.e. 34.02 percent of the sample). What is more, no significant Spearman coefficient correlation was found between financial literacy and saving choices (the same was true for debt literacy and debt choices as well as investment literacy and choices).

Table 6

Correlations between financial capabilities variables

\begin{tabular}{l|c|c|c|c}
\hline \multicolumn{1}{c|}{ Pair of items } & $\mathbf{N}$ & $\begin{array}{c}\text { Spearman's rank } \\
\text { correlation } \\
\text { coefficient: }\end{array}$ & $\mathbf{T ( N - 2 )}$ & Sig. \\
\hline $\begin{array}{l}\text { Financial literacy \& usage of financial } \\
\text { products }\end{array}$ & 194 & 0.29 & 4.26 & $0.000^{*}$ \\
\hline $\begin{array}{l}\text { Investment literacy \& usage of financial } \\
\text { products }\end{array}$ & 194 & 0.35 & 5.19 & $0.000^{*}$ \\
\hline Debt literacy \& usage of financial products & 194 & 0.19 & 2.67 & $0.008^{*}$ \\
\hline Financial literacy \& usage of debt products & 194 & 0.16 & 2.20 & $0.029^{*}$ \\
\hline Investment literacy \& usage of debt products & 194 & 0.20 & 2.84 & $0.005^{*}$ \\
\hline Debt literacy \& usage of debt products & 194 & 0.18 & 2.54 & $0.012^{*}$ \\
\hline $\begin{array}{l}\text { Financial literacy \& usage of investment } \\
\text { products }\end{array}$ & 194 & 0.11 & 1.57 & 0.118 \\
\hline $\begin{array}{l}\text { Investment literacy \& usage of investment } \\
\text { products }\end{array}$ & 194 & 0.09 & 1.21 & 0.227 \\
\hline $\begin{array}{l}\text { Debt literacy \& usage of investment } \\
\text { products }\end{array}$ & 194 & 0.02 & 0.32 & 0.749 \\
\hline
\end{tabular}

* significant at 5 percent level

Source: own study.

Thirdly, the study evaluates different types of essential financial behaviours, which is in fact the ability to cope with financial distress, shocks and difficulties (Dubois and Rousseau 2008). To do so the author identified 
financial threats which may increase the probability of becoming financially deprived or which may increase the risk of poverty, also called vulnerability (Panek 2011: 157). In order to achieve this, the author asked the heads of households how they deal with financial shocks in soft and extreme forms, unexpected expenditures or handle financial complaints (getting help) as defined by McCarthy (2011). First of all, it turned out that most households very often keep up with their expenses during a typical month. The median score, the number for answers between 'rather often' and 'always' was 166 out of 185 , or 89.72 percent of the subsample. Moreover, they were generally not overdue with payment of bills; the median score, 116 out of 194, i.e. 59.79 percent of the subsample. On top of that, when they are faced with the lack of cash during a typical month (with no indication of precise value) they show mainly responsible behaviour by first answering: 'I keep my spending down or I take overtime in my work' (61 out of 166, or 36.75 percent of the subsample), then 'I take out a loan in my bank or use my debit card limit' ( 60 out of 166, or 24.1 percent of the subsample), or the answer 'I never reach the cash limit' (26 out of 166 , or 15.66 percent of the subsample). If they are confronted with the actual amounts, such as unexpected expenditure, i.e. PLN 1500 which is approximately one month's salary and PLN 15,000 which is approximately one year's salary, one may observe how fragile this pattern might be. In the first case (PLN 1500), the vast majority will not be able to cover that expenditure or simply will not be able to figure out what to do (171 out of 194 , which is 88.15 percent of the sample), the remainder of those polled will borrow from family members or draw money from savings ( 17 out of 194 , which is 8.76 percent of the sample) or rarely will use credit products (6 out of 194, i.e. 3.09 percent of the sample). In the second case (PLN 15,000), most of the households will replicate the previous behaviour pattern (102 out of 194, or 52.55 percent of the sample). Moreover, many more will borrow from family members, draw money from savings (44 out of 194, i.e. 22.68 percent of the sample) or will use credit products (43 out of 194, i.e. 22.16 percent of the sample). Additionally, none of the respondents (PLN 1500 expenditure) and only 3 of them (PLN 15,000 expenditure) will use loan from the 'fridge' banks when confronted with unexpected expenses.

To understand this pattern even better, the author asked two additional questions concerning income aspirations and savings protection level in case of unexpected expenditure (due to car or house repair) as well as loss of income (due to an illness). Surprisingly, a part of the sample simply do not know (in the case of expected income 41 out of 194, i.e. 21.13 percent of the 
sample and in the case of unexpected life events 71 out of 194, i.e. 37.17 percent of the sample). This proves that low-income households may have great problems with understanding their financial potential and risks associated with financial insecurity (Lusardi et al. 2011). In this situation, risk literacy and risk management skills might be essential in building a complete picture of the financial capability of low-income households (Jajuga et al. 2015, Banerjee and Duflo 2011). The rest of the interviewed households (the vast majority, 131 out of 194, i.e. 67.53 percent of the sample) are not satisfied with the current income level and would feel secure with the median income of PLN 3000 (doubled on average). This shows that the aspiration gap is rather low which means that low-income households may have little incentive to raise their financial situations (Ray 2006: 412) and prefer to choose the "hedgehog strategy" based on passivity and lack of mobility (Bukraba-Rylska 2013: 359). Therefore, this also results in the way households answer the question about savings protection level in the case of unexpected expenditure (which was then corrected by the current income level). From the remaining 120 households, 34 of them (i.e. 17.8 percent of the subsample) would be satisfied with 3 months' salary protection, 16 (or 8.38 percent of the subsample) would be satisfied with 6 months' salary protection, 21 (or 10.99 percent of the subsample) would be satisfied with 12 months' salary protection, 22 (or 11.52 percent of the subsample) would be satisfied with between 1 and 3 years' salary protection, and finally, 27 (or 14.14 percent of the subsample) would be satisfied with more than 3 years' salary protection. Even though it looks like a very responsible financial behaviour, the median score is only PLN 15,000. This proves that in most cases, the low-income households are very responsible but unfortunately, they cannot imagine a sum of money bigger than one year's salary as a consequence of structural constraints (Robeyns 2017).

Finally, to build a complete picture of financial capability, the author asked questions about making use of insurance and saving for retirement. This attitude towards insurance may justify a low aspiration of income level as well as low savings protection expectations. Furthermore, most respondents do not save for retirement (162, i.e. 83.51 percent of the sample), even though they expect to have the same (66 out of 194, i.e. 34.02 percent of the sample) or a worse (86 out of 194, i.e. 44.32 percent of the sample) level of quality of life during retirement (which is a wrong assumption, taking into account the responsibility shift in that case). What is more, they claim that they are equally responsible for their level of life quality during retirement (the median score). When it comes to handling insurance, households behave quite responsibly and most of the respondents 
(135 out of 191, or 70.68 percent of the subsample) have more than one insurance contract. In the case of insurance products, they hold obligatory car insurance (139 out of 194, or 71.64 percent of the subsample) but do not take out Comprehensive Cover (only 17 out of 139). However, quite surprisingly most of them hold house insurance (118 out of 194), less than half life insurance (81 out of 194) and quite a small number - AD\&D insurance (45 out of 194). What is more, they generally diversify their insurance provider and do not sign insurance contracts with only one provider ( 90 out of 135, i.e. 66.67 percent of the subsample).

Table 7

Descriptive statistics for selected financial behaviour variables

\begin{tabular}{l|c|c|c|c|c|c}
\hline & $\mathbf{N}$ & Average & Median & Min & Max & S.D. \\
\hline $\begin{array}{l}\text { Keeping up with expenses in a typical } \\
\text { month (6 mod.) }\end{array}$ & 185 & 4.94 & 5.00 & 1.00 & 6.00 & 1.08 \\
\hline $\begin{array}{l}\text { Keeping up with the budget in last year } \\
\text { (4 mod.) }\end{array}$ & 194 & 3.46 & 4.00 & 1.00 & 4.00 & 0.80 \\
\hline $\begin{array}{l}\text { Dealing with unexpected PLN 1500 } \\
\text { expenditure (5 mod.) }\end{array}$ & 194 & 4.44 & 5.00 & 1.00 & 5.00 & 1.22 \\
\hline $\begin{array}{l}\text { Dealing with unexpected PLN 1500 } \\
\text { expenditure (5 mod.) }\end{array}$ & 194 & 3.11 & 4.00 & 1.00 & 5.00 & 1.56 \\
\hline $\begin{array}{l}\text { Dealing with unexpected expenditure } \\
\text { in general (5 mod.) }\end{array}$ & 166 & 3.22 & 4.00 & 0.00 & 5.00 & 1.29 \\
\hline $\begin{array}{l}\text { Unexpected life events protection level as } \\
\text { a number of monthly salaries (5 mod.) }\end{array}$ & 191 & 2.84 & 2.00 & 1.00 & 6.00 & 1.87 \\
\hline Income protection level (3 mod.) & 194 & 1.46 & 2.00 & 0.00 & 2.00 & 0.82 \\
\hline Number of insurance holding (5 mod.) & 191 & 2.10 & 2.00 & 0.00 & 5.00 & 1.19 \\
\hline $\begin{array}{l}\text { Saving for retirement outside Social } \\
\text { security (dichotomous) }\end{array}$ & 194 & 0.16 & 0.00 & 0.00 & 1.00 & 0.37 \\
\hline Responsibility for retirement (3 mod.) & 183 & 1.91 & 2.00 & 1.00 & 3.00 & 0.61 \\
\hline $\begin{array}{l}\text { Expectation of life level after retiring } \\
\text { (6 mod.) }\end{array}$ & 194 & 3.28 & 4.00 & 1.00 & 6.00 & 1.57 \\
\hline
\end{tabular}

Source: own study.

\subsection{Factor Analysis}

In order to denote and summarize the chosen data as well as indicate some latent determinants of financial capability, the factor analysis was adopted (Atkinson et al. 2006; Mckay 2011). First, data transformation was carried out. This helped to rescale different values by variables by their rank in ascending order of ordinal numbers (between 3 and 8 modes). Hence, from the financial literacy, financial inclusion and financial behaviour set of 
variables, 20 of them were selected to execute a factor analysis. Afterwards, the initial extraction was conducted with seven factors. Second, the measure of internal consistency for each variable as well as for the whole group of variables was inspected (Cronbach's alpha $=0.719688$, Cronbach's Alpha based on standardized items $=0.726142$ ).

\section{Table 8}

Cronbach's alpha for selected variables

$$
\text { Average }=\mathbf{5 0 . 3 0 0 0} \text { S.D. }=8.71260 \quad \mathrm{~N}=140
$$

Cronbach's alpha $=\mathbf{0 . 7 1 9 6 8}$ Cronbach's Alpha based on standardized items $=\mathbf{0 . 7 2 6 1 4 2}$

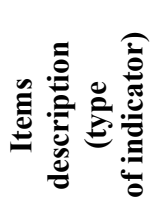

\begin{tabular}{l|l|l|l|l|l}
\hline Numeracy (3 mod.) & 48.721 & 67.072 & 8.1898 & 0.437 & 0.697 \\
\hline Risk literacy (3 mod.) & 48.243 & 66.498 & 8.1546 & 0.407 & 0.698 \\
\hline Financial literacy (4 mod.).) & 49.571 & 67.959 & 8.2437 & 0.434 & 0.698 \\
\hline Investment literacy (5 mod.) & 48.379 & 64.764 & 8.0476 & 0.401 & 0.697 \\
\hline Debt literacy (3 mod.) & 49.593 & 71.927 & 8.4810 & 0.221 & 0.714 \\
\hline Self-control test (3 mod.) & 49.393 & 70.567 & 8.4004 & 0.369 & 0.706 \\
\hline $\begin{array}{l}\text { Sort of payment methods for day-to-day } \\
\text { purchases (5 mod.) }\end{array}$ & 48.364 & 70.389 & 8.3898 & 0.278 & 0.710 \\
\hline Active usage of bank account (5 mod.) & 46.557 & 62.447 & 7.9023 & 0.404 & 0.697 \\
\hline $\begin{array}{l}\text { Type of payment methods for ongoing expenses } \\
\text { (6 mod.) }\end{array}$ & 46.750 & 85.873 & 9.2668 & -0.573 & 0.778 \\
\hline Usage of financial products (4 mod.) & 47.179 & 70.418 & 8.3916 & 0.282 & 0.710 \\
\hline Number of working family members (6 mod.) & 48.636 & 67.674 & 8.2264 & 0.339 & 0.704 \\
\hline Households' income range (8 mod.) & 46.193 & 72.884 & 8.5372 & 0.138 & 0.719 \\
\hline $\begin{array}{l}\text { Keeping up with ongoing expenses in a typical } \\
\text { month (6 mod.) }\end{array}$ & 48.107 & 68.153 & 8.2555 & 0.435 & 0.699 \\
\hline Selected financial planning skills (5 mod.) & 48.607 & 67.110 & 8.1921 & 0,324 & 0.706 \\
\hline $\begin{array}{l}\text { Self-perception of household's economic } \\
\text { situation (6 mod.) }\end{array}$ & 47.571 & 63.031 & 7.9392 & 0.404 & 0.697 \\
\hline $\begin{array}{l}\text { Dealing with unexpected PLN 1500 expenditure } \\
\text { (5 mod.) }\end{array}$ & 45.279 & 69.301 & 8.3247 & 0.283 & 0.709 \\
\hline Financial stability in the last year (4 mod.) & 46.707 & 71.536 & 8.4579 & 0.329 & 0.709 \\
\hline Keeping up with the budget in last year (4 mod.) & 45.621 & 70.535 & 8.3985 & 0.274 & 0.710 \\
\hline Number of insurance holding (5 mod.) & 48.250 & 65.545 & 8.0960 & 0.327 & 0.706 \\
\hline $\begin{array}{l}\text { Self-perception of household finance } \\
\text { management (6 mod.) }\end{array}$ & 47.979 & 66.764 & 8.1709 & 0.400 & 0.699 \\
\hline & & & &
\end{tabular}

Source: own study. 
Table 9

Scores of Sampling Adequacy

\begin{tabular}{l|l|l}
\hline \multicolumn{2}{l|}{ Kaiser-Mayer-Olkin measure of adequacy } & 0.719 \\
\hline Bartlett 's test of sphericity & Approx. Chi Square & $\mathbf{7 2 3 . 6 4 3}$ \\
\hline & Df & $\mathbf{2 1 0}$ \\
\hline & Sig. & $\mathbf{0 . 0 0 0}$ \\
\hline
\end{tabular}

Source: own study.

Table 10

Factor Analysis using Principal Component Factors

\begin{tabular}{|c|c|c|c|c|c|c|c|}
\hline 总 & 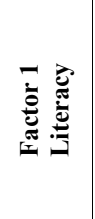 & 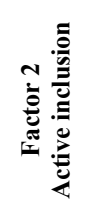 & 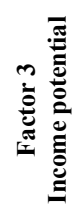 & 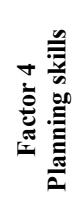 & 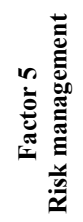 & 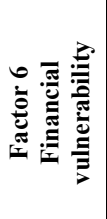 & 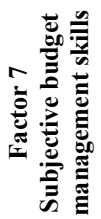 \\
\hline Numeracy (3 mod.) & $0.792 *$ & 0.06 & 0.005 & 0.051 & 0.157 & -0.032 & 0.075 \\
\hline Risk literacy (3 mod.) & $0.677^{*}$ & 0.084 & 0.229 & 0.006 & 0.204 & -0.03 & 0.101 \\
\hline Debt literacy (3 mod.) & $0.643^{*}$ & 0.065 & -0.102 & -0.121 & -0.092 & 0.097 & 0.178 \\
\hline Investment literacy ( 5 mod.) & 0.597 & -0.045 & 0.026 & 0.321 & 0.137 & 0.024 & -0.384 \\
\hline Financial literacy (4 mod.).) & 0.555 & 0.169 & 0.17 & 0.235 & -0.239 & 0.002 & -0.282 \\
\hline Self-control test (3 mod.) & 0.49 & -0.106 & 0.474 & 0.083 & -0.061 & 0.091 & 0.108 \\
\hline $\begin{array}{l}\text { Type of payment methods for day-to-day } \\
\text { purchases ( } 5 \text { mod.) }\end{array}$ & -0.006 & $0.78^{*}$ & -0.011 & 0.084 & 0.019 & -0.039 & -0.034 \\
\hline Active usage of bank account ( 5 mod.) & -0.018 & $0.776^{*}$ & 0.028 & 0.083 & 0.117 & -0.035 & 0.008 \\
\hline $\begin{array}{l}\text { Type of payment methods for ongoing } \\
\text { expenses ( } 6 \text { mod.) }\end{array}$ & 0.197 & $0.771^{*}$ & 0.154 & -0.103 & -0.011 & 0.026 & 0.104 \\
\hline Usage of financial products ( 4 mod.) & 0.118 & $0.604 *$ & $-0,067$ & 0.45 & -0.012 & 0.237 & -0.253 \\
\hline $\begin{array}{l}\text { Number of working family members } \\
\text { (6 mod.) }\end{array}$ & 0.054 & 0.051 & $0.849^{*}$ & -0.053 & .033 & -0.081 & -0.1 \\
\hline Households' income range (8 mod.) & .077 & 0.093 & $0.834^{*}$ & 0.141 & 187 & 0.051 & 0.04 \\
\hline $\begin{array}{l}\text { Keeping up with expenses in a typical } \\
\text { month (6 mod.) }\end{array}$ & .075 & -0.162 & 241 & $724 *$ & -0.013 & -0.212 & $\frac{0.105}{0.060}$ \\
\hline Selected financial planning skills (5 mod.) & 0.044 & 0.25 & 166 & $0.71 *$ & 0.096 & 0.066 & 0.069 \\
\hline $\begin{array}{l}\text { Self-perception of household's economic } \\
\text { situation (6 mod.) }\end{array}$ & .065 & -0.337 & -0.404 & .517 & .061 & 0.083 & -0.218 \\
\hline $\begin{array}{l}\text { Dealing with unexpected } 1500 \text { PLN } \\
\text { expenditure (5 mod.) }\end{array}$ & 0.165 & 0.123 & 018 & .012 & $0.856^{*}$ & -0.089 & -0.054 \\
\hline Financial stability in the last year $(4 \mathrm{mo}$ & -0.071 & -0.031 & 326 & 362 & 0.475 & 0.234 & -0.006 \\
\hline $\begin{array}{l}\text { Keeping up with the budget in last year } \\
(4 \mathrm{mod}) \text { ) }\end{array}$ & 062 & 1 & 78 & 374 & 42 & $-0.725^{*}$ & 0.045 \\
\hline Number of insurance holding ( 5 mod.) & 177 & 0.167 & 226 & 311 & 214 & $0.646^{*}$ & 0.079 \\
\hline $\begin{array}{l}\text { Self-perception of household finance } \\
\text { management ( } 6 \text { mod.) }\end{array}$ & 0.167 & -0.004 & 0.005 & 0.224 & -0.041 & 0.017 & $0.826^{*}$ \\
\hline
\end{tabular}

Notes: Extraction method: Principal Component Analysis, 7 factors extracted, 15 iteration required, rotation: varimax with Kaiser normalization; * values equal or exceeding 0.6 threshold for identifying significant factor loading, significant at 5 per cent level.

Source: own study. 
Third, the suitability for factor analysis was examined (the Kaiser-MayerOlkin measure of adequacy $=0.719$, Bartlett's test of sphericity 0.000 ).

Based on Kaiser's measure and Cattell's scree test, seven factors were selected for the next and the final stage of the analysis based on the principal component analysis. Then, the orthogonal rotation method (varimax) with Kaiser normalization and 0.6 threshold value for selecting significant factor loadings were chosen to conduct the computation (see also: Białowąs 2013). All values higher than 0.6 were flagged with an asterisk. The interpretation of the items loading showed the existence of seven latent factors named as follows:

All seven factors explain 63.27 percent of total variance. Moreover, the three most important factors are: factor 1, which explains 12.372 percent, factor 2 explaining 11.814 percent and factor 3 explains 9.792 percent of the highest percentage total variance, which constitutes 33.977 percent of total variance.

Table 11

Factor loadings corresponding to the financial capability variables

\begin{tabular}{|c|c|c|c|c|c|c|c|c|c|}
\hline \multirow[b]{2}{*}{ 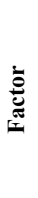 } & \multicolumn{3}{|c|}{$\begin{array}{c}\text { Initial } \\
\text { eigenvalues }\end{array}$} & \multicolumn{3}{|c|}{$\begin{array}{c}\text { Extraction sums } \\
\text { of squared loadings }\end{array}$} & \multicolumn{3}{|c|}{$\begin{array}{c}\text { Rotation sums } \\
\text { of squared loadings }\end{array}$} \\
\hline & है & ○。 & 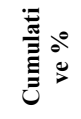 & है & 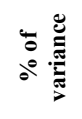 & 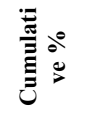 & $\stackrel{\text { है }}{\circ}$ & 흘 & 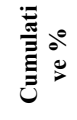 \\
\hline 1 & 4.245 & 20.212 & 20.212 & 4.245 & 20.212 & 20.212 & 2.598 & 12.372 & 12.372 \\
\hline 2 & 2.194 & 10.447 & 30.659 & 2.194 & 10.447 & 30.659 & 2.481 & 11.814 & 24.185 \\
\hline 3 & 1.856 & 8.836 & 39.495 & 1.856 & 8.836 & 39.495 & 2.056 & 9.792 & 33.977 \\
\hline 4 & 1.473 & 7.013 & 46.508 & 1.473 & 7.013 & 46.508 & 1.669 & 7.947 & 41.924 \\
\hline 5 & 1.315 & 6.26 & 52.768 & 1.315 & 6.26 & 52.768 & 1.605 & 7.643 & 49.567 \\
\hline 6 & 1.157 & 5.511 & 58.279 & 1.157 & 5.511 & 58.279 & 1.539 & 7.328 & 56.896 \\
\hline 7 & 1.048 & 4.991 & 63.27 & 1.048 & 4.991 & 63.27 & 1.339 & 6.374 & 63.27 \\
\hline 8 & 0.874 & 4.162 & 67.432 & & & & & & \\
\hline 9 & 0.808 & 3.848 & 71.28 & & & & & & \\
\hline 10 & 0.771 & 3.67 & 74.95 & & & & & & \\
\hline 11 & 0.683 & 3.254 & 78.204 & & & & & & \\
\hline 12 & 0.649 & 3.092 & 81.296 & & & & & & \\
\hline 13 & 0.595 & 2.832 & 84.128 & & & & & & \\
\hline 14 & 0.579 & 2.756 & 86.884 & & & & & & \\
\hline 15 & 0.535 & 2.549 & 89.433 & & & & & & \\
\hline 16 & 0.515 & 2.451 & 91.884 & & & & & & \\
\hline 17 & 0.429 & 2.043 & 93.927 & & & & & & \\
\hline 18 & 0.381 & 1.812 & 95.739 & & & & & & \\
\hline 19 & 0.351 & 1.673 & 97.412 & & & & & & \\
\hline 20 & 0.312 & 1.485 & 98.896 & & & & & & \\
\hline 21 & 0.232 & 1.104 & 100 & & & & & & \\
\hline
\end{tabular}

Source: own study. 
From the perspective of the items: factor 1 explains 79.2 percent of the variance of numeracy (which is estimated as the squared correlation score), 67.7 percent of the variance of risk literacy and 64.3 percent of the total financial literacy score variance, factor 2 explains 78.0 percent of the variance of type of payment methods for day-to-day purchases, 77.6 percent of the variance of active usage of bank account, 77.1 percent of the variance of type of payment methods for ongoing expanses, as well as 60.4 percent of the variance of usage of financial products, factor 3 explains 84.9 percent of number of working family members, and 83.4 percent of the households income range. Then, the factors' average values for some demographic and behavioural characteristics were computed, but no significant differences between age, sex, educational level, marital status, uncertainty control, short time preference etc., were found. To sum up, the factor analysis confirmed the high importance of literacy skills (especially risk and debt literacy), active inclusion as well as income level as significant latent factors in shaping financial capability of low-income households.

\subsection{Logistic regression results}

The third stage of the study was aimed at providing a deeper understanding of the relation between subjective poverty and a group of demographic, behavioural and financial capability characteristics. Special attention was given to a group of households, which despite having a low income, they still feel financially satisfied. Hence, the logistic regression model was constructed, where y is dependent variable "feeling financially satisfied", $x$ represents a set of characteristics posited to influence the feeling of being economically well-off (including financial literacy and financial behaviour variables, as well as demographic and behavioural variables), $\beta$ is a set of parameters to be estimated, $\varepsilon$ represents the error, and $\mathrm{i}$ is the observation number. The dichotomous dependent variables were constructed from categorical indicator ( 7 mod.); feeling financially satisfied is here defined as a subjective feeling of financial situation indicated between "very good, good and rather good". Hence, the group of 85 respondents who are objectively poor in terms of low-income, classified their households as being financially secure, the rest, which is 109 , classified themselves as deprived in terms of low-income (both subjectively and objectively).

The author began by examining the role of demographic variables. Then, behavioural and attitudinal variables (one by one) were added to the model, next continuing with the set of financial literacy, financial capability and 
finally with financial behaviour variables. The author adopted the down top approach by analyzing the incremental chi-square test (LR chi-square test) between previous model at $p$ level less than 5 percent as well as pseudo- $\mathrm{R}^{2}$.

Table 12

Pseudo R2 scores for group characteristics

\begin{tabular}{l|r|r|r|r|r}
\hline & \multicolumn{5}{|c}{ Characteristics } \\
\cline { 2 - 6 } & Demographic & $\begin{array}{c}\text { Subjective } \\
\text { happiness }\end{array}$ & $\begin{array}{c}\text { Financial } \\
\text { literacy }\end{array}$ & $\begin{array}{c}\text { Financial } \\
\text { inclusion }\end{array}$ & \multicolumn{1}{c}{ Behavioural } \\
\hline LR chi-square & 227.0214 & 194.8447 & 152.8502 & 132.9225 & 125.6513 \\
\hline Prob. chi-square & 0.000 & 0.000 & 0.000 & 0.000 & 0.007 \\
\hline Pseudo R $^{2}$ & 0.146 & 0.165 & 0.206 & 0.232 & 0.275 \\
\hline
\end{tabular}

Source: own study.

The inclusion of all four groups of variables raises the pseudo- $\mathrm{R}^{2}$ from 0.1464 to 0.2745 , suggesting that all characteristics play an important role in predicting adaptation. Moreover, each of these variables adds to the fit of the model. What is interesting, the biggest improvement in both is the incremental LR chi-square test and pseudo- $\mathrm{R}^{2}$ is achieved by adding financial literacy characteristics (41.99 and 0.041264 respectively). It seems

Table 13

Logistic regression results

\begin{tabular}{|c|c|c|c|c|c|c|c|c|c|}
\hline & 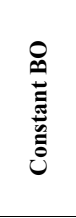 & 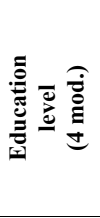 & 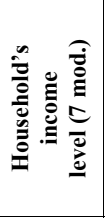 & 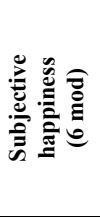 & 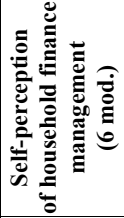 & 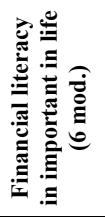 & 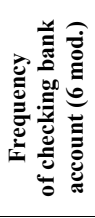 & 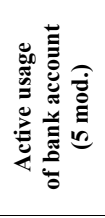 & 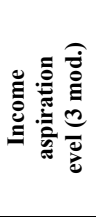 \\
\hline Beta & -3.434 & 0.555 & 0.5197 & 0.388 & 0.130 & -0.386 & -0.091 & 0.6102 & -0.930 \\
\hline Std. error & 2.169 & 0.280 & 0.1663 & 0.336 & 0.2896 & 0.217 & 0.205 & 0.240 & 0.371 \\
\hline$T(116)$ & -1.583 & 1.981 & 3.125 & 1.156 & 0.4496 & -1.781 & -0.445 & 2.548 & -2.508 \\
\hline P-value & 0.1161 & 0.050 & 0.002 & 0.250 & 0.654 & 0.0776 & 0.657 & 0.012 & 0.014 \\
\hline$-95 \%$ CL & -7.730 & 0.000 & 0.1903 & -0.277 & -0.443 & -0.816 & -0.498 & 0.136 & -1.665 \\
\hline$+95 \% \mathrm{CL}$ & 0.8626 & 1.109 & 0.849 & 1.053 & 0.704 & 0.0434 & 0.315 & 1.085 & -0.196 \\
\hline Wald chi-square & 2.506 & 3.923 & 9.766 & 1.336 & 0.202 & 3.171 & 0.198 & 6.491356 & 6.291 \\
\hline P-value & 113 & 0.048 & 0.001 & 0.248 & 0.653 & 0.075 & 0.656 & 0.0108 & 0.0121 \\
\hline OR (unit ch) & 0.0323 & 1.741 & 1.681 & 1.474 & 1.139 & 0.680 & 0.913 & 1.841 & 0.395 \\
\hline$-95 \%$ CL & 0.000 & 1.000 & 1.209 & 0.7583 & 0.6419 & 0.442 & 0.608 & 1.146 & 0.189 \\
\hline$+95 \% \mathrm{CL}$ & 2.369 & 3.032 & 2.337 & 2.865 & 2.021 & 1.044 & 1.370 & 2.958 & 0.822 \\
\hline OR (range) & & 5.2813 & 63.91 & 4.719 & 1.684 & 0.145 & 0.634 & 11.482 & 0.156 \\
\hline$-95 \% \mathrm{CL}$ & & 1.000 & 4.584 & 0.3306 & 0.1697 & 0.017 & 0.083 & 1.722 & 0.0358 \\
\hline$+95 \% \mathrm{CL}$ & & 27.890 & 891.091 & 67.358 & 16.699 & 1.242 & 4.832 & 76.575 & 0.676 \\
\hline
\end{tabular}

Notes: $\mathrm{N}=125$; final loss: $62.826 ; \operatorname{chi}^{2}(6)=47.564 ; \mathrm{p}=0.000$

Source: own study. 
that financial literacy is not only the main latent factor in financial capability of low-income households, but also a central component in adaptation to a low-income situation. Finally, the logit model was used to examine the various effects of the demographic, literacy, capability and behavioural characteristics perception.

The results show that demographic characteristics (education and income level), financial inclusion variable (active usage of bank account) as well as behavioural variable (income aspiration level) are the most important and statistically significant across all characteristics. In particular, the negative income aspiration level coefficients imply that households with high-income expectations are more likely to feel financial frustration and it may affect their subjective perception of financial situation (Ray 2006). On the contrary, households which are doing well financially, have a higher education level, do not treat finance as a central part of their life and are financially included (but do not check their account too often), are more likely to feel financially satisfied with their low-income. The highest odd ratio is estimated for active inclusion (score 1.84). The second highest education level variable (score 1.74) and the third highest is income level (1.68). Thus, the author may interpret these values as almost twice more likely to feel financially satisfied when the household is financially included, have a higher income and education level. The overall essence of the estimated model is very high (the p level is equal to 0.00000 ). In order to evaluate the fit of the presented logistic regression model the residuals were evaluated especially the observed versus the predicted proportions were diagnosed. The odds ratio is 13.074 , which means that classification is better than the one selected by chance.

\section{SUMMARY AND DISCUSSION}

The paper points out a number of key results and conclusions concerning the level of financial capability among low-income households from rural and peripheral parts of Poland. First, financial literacy among these households is very low, which is even more important when we take into account the results from the factor analysis. It seems that when assessing financial capability there is a positive literacy factor underlining the importance of numeracy, risk literacy and debt literacy in particular. Their role might be highly relevant, severely restrictive, or they may secure some of the financial behaviour (Lusardi 2011, Lusardi and Mitchell 2007, Hastings et al. 2012, Kempson et al. 2013). As stated by Lusardi (2008: 
15-6): "As it was impossible to live and operate efficiently in the past without being literate (...), so it is very hard to live and operate efficiently today without being financially literate (...). Individuals need to know how to read and write financially". Thus the low level of financial literacy may result in the incapability to: first, use a full range of financial opportunities, second, prevent households from having the capability to make responsible financial choices (being able to understand product mechanisms and product descriptions), third, put at risk some other core functionalities, such as psychological health (Marmot 2005; Pollack and Lynch 2009).

Moreover, it is important to underline that modes of financial behaviour among low-income households are rather high and their role is clearly presented by factor analysis (especially factors 2, 3, 4, 5 and 6). This is especially true for the "financial management skills" (factors 2 and 4) which are in fact abilities allowing to manage a financial budget and keep track of expenditure (Kempson et al. 2013; Collins et al. 2009; Hastings et al. 2012). It seems that being financially illiterate does not stop low-income households from building the financial management skills, which might be more linked with survival skills and rooted in the local culture than with financial education attendance (Holzmann et al. 2013; Akerlof and Kranton 2000). As stated by Collins et al. (2009: 3) "money management is, for the poor, a fundamental and well-understood part of everyday life". Apparently there are some social learning processes which shape preferences and help low-income households from rural parts of Poland to find some other way, rather than through financial education, to achieve a satisfactory level of financial behaviour (Sen 2002: 164; Sztompka 2007: 26).

Low-income households behave generally responsibly because having little forces them to be very careful in terms of financial choices (Banerjee and Duflo 2011: IX; Shah et al. 2012; Mullainathan and Shafir 2014). On the other hand, the lack of more sophisticated financial behaviour might be explained by the fact that low-income households may first act (begin to accumulate savings) and then, if motivated, build their financial literacy necessary to act responsibly (Bertrand et al. 2006: 15). This means that if there is no action, there is no knowledge. Third, financial behaviour in general shows a high level of accountability but lack of long-term planning and misunderstanding of the real risk associated with unemployment, illness or disability (only one year' saving protection). Kempson et al. (2013: XXI) presented a similar result in a study which included ten low-income countries. They stated: "many of the countries included a group of people with very low incomes who were very good at managing their money day to 
day but either had short-term planning horizons or a low propensity to save (or both)".

Finally, the logistic regression showed that not only demographic (education and income level) but also financial inclusion factors matter greatly for adaptation to low-income situations (measured by marginal effects of pseudo- $\mathrm{R}^{2}$ ). In the short term, adaptation to a low income might have a positive effect (reducing a financial stress and frustration), especially when structural constraints do not allow to increase the household's income. However, in the long term it may have a destructive impact on the financial capability open to low-income households. As indicated by Robeyns (2017: 139), "a group that is systematically socialized to have low aspirations and ambitions will perhaps not put certain capabilities on its list". This is especially true for post-communist countries, where risk avoidance, passiveness and survival attitude (which results in short-term thinking) are country folk's immanent values, and which still makes it important components of their financial capability (Kochanowicz et al. (eds.) 2007: 37). Moreover, according to Goszczyńska (2010: 17), "the social consciousness was the toughest to change" after the transition in Poland. Thus to better understand the financial capability of low-income households, the analysis of institutional, environmental and social constraints is necessary (Topińska 1999; Marody 1990, Akerlof and Kranton 2000, Sztompka 2007, Wilkin 2016, Robeyns 2017).

\section{REFERENCES}

Akerlof, G. A., Kranton, R. E., Economics and Identity, "The Quarterly Journal of Economics", no. 115 (3), pp. 715-753, 2000.

Akerlof, G. A., Shiller, R. J., Phishing for Phools: The Economics of Manipulation and Deception. Princeton University Press, New York 2015.

Anand, P., Lea. S., The psychology and behavioural economics of poverty, "Journal of Economic Psychology", no. 32, pp. 284-293, 2011.

Arrowsmith, S., Pignal, J., Initial Findings from the 2009 Canadian Financial Capability Survey (May 10, 2012). Research Paper Task Force on Financial Literacy, Available at: http://financialliteracyincanada.com, 2010.

Atkinson, A. B., Multidimensional Deprivation: Contrasting Social Welfare and Counting Approaches, "Journal of Economic Inequality", no. 1(1), pp. 51-65, 2003.

Atkinson, A., McKay, S., Kempson, E., Collard, S., Levels of Financial Capability in the UK: Results of baseline survey (May 10, 2012). FSA Customer Research 47, Bristol, Available at: http://www.fca.org.uk/your-fca/documents/research/fsa-levels-of-financial-capabilityin-the-uk-results-of-a-baseline-survey, 2006. 
Atkinson, A., Messy, F.-A., Assessing Financial Literacy in 12 Countries An OECD Pilot Exercise (May 10, 2012). Netspar Discussion Papers 01/2011. OECD Financial Affairs Division. Paris 2012.

Banerjee, A. V., Duflo, E., Poor Economics. Penguin Books, 2011.

Bertrand, M., Mullainathan, S., Shafir, E., A behavioral-economics view of poverty, "American Economic Review”, no. 94(2), pp. 419-423, 2004.

Bertrand, M., Mullainathan, S., Shafir, E., Behavioral economics and marketing in aid of decision making among the poor, "Journal of Public Policy \& Marketing", no. 25, pp. 8-25, 2006.

Białowąs, S., Zachowania oszczędnościowe w polskich gospodarstwach domowych. Postawy, determinanty, model [Saving behaviour of the Polish Households. Attitudes, determinants, model]. Wydawnictwo Uniwersytetu Ekonomicznego w Poznaniu [Poznań University of Economics and Business Publishing House], Poznań, 2013.

Bogacka-Kisiel, E., (ed.), Finanse osobiste. Zachowania, Produkty, Strategie [Personal finance. Behaviour, products, strategies]. Wydawnictwo Naukowe PWN [Polish Scientific Publishers PWN], Warsaw 2012.

Bradshaw, J., Finch, N., Overlaps in Dimensions of Poverty, "Journal of Social Policy", no. 32, pp. 513-525, 2003.

Bukraba-Rylska, I., Socjologia wsi polskiej [Sociology of the Polish Countryside]. Wydawnictwo Naukowe PWN [Polish Scientific Publishers PWN], Warsaw 2013.

Cokely, E. T, Galesic, M., Schulz, E., Hhazal, S., Garcia-Retamero, R., Measuring Risk Literacy: The Berlin Numeracy Test, "Judgment and Decision Making", no. 7(1), pp. 2547, 2012.

Collins, D., Mordach, J., Rutherford, S., Ruthven, O., Portfolios of the Poor. How the World's Poor Live on $2 \$$ a Day. Princeton University Press, Princeton \& Oxford 2009.

Dubois, J-L., Rousseau, S., Reinforcing Households' Capabilities as a Way to Reduce Vulnerability and Prevent Poverty in Equitable Terms, [in:] Comim, F., Qizilbash, M. Alkire, S. (eds.), The Capability Approach: Concepts, Measures and Applications, pp. 421-436. Cambridge University Press, Cambridge 2008.

European Parliament, Sprawozdania w sprawie ochrony konsumenta: poprawa edukacji konsumenckiej $i$ wiedzy na temat kredytów i finansów. Komisja Rynku Wewnętrznego Ochrony Konsumentów [Reports on consumer's protection: Improvement of consumer's education and knowledge on credit and finance. Commission of Domestic Market Consumers' Protection] (May 10, 2012). Available at: www.europarl.europa. eu/meetdocs/.../727352pl.pdf, 2008.

Flejterski, S., Świadomość ekonomiczna i społeczna jako determinanta kondycji ekonomicznej gospodarstw domowych na tle badań (wtórnych i pierwotnych) [The economic and social awareness as a determinant of households' economic condition on background of research (secondary and primary)], [in:] Świecka, B. (ed.), Bankructwa gospodarstw domowych. Perspektywa ekonomiczna i spoleczna [Bankruptcy of households. The economic and social view], pp. 92-143. Difin, Warsaw 2008.

Fleurbaey, M., Capabilities, Functionings and Refined Functionings. "Journal of Human Development", no. 7(3), pp. 299-31, 2006. 
Friske, K., (ed.), Marginalność i procesy marginalizacji [Marginality and marginalizing processes]. Instytut Pracy i Spraw Socjalnych, Instytut Polityki Społecznej UW [Institute of Labour and Social Studies, The Institute of Social Policy of the University of Warsaw], Warsaw 1999.

FSA and BSA (Financial Services Authority and Basic Skills Agency), Adult Financial Capability Framework. Government of the United Kingdom (May 10, 2012).. London, Available at: http://www.bris.ac.uk/geography/research/pfrc/, 2002.

Gigerenzer, G., Edwards, A., Simple tools for understanding risks: from innumeracy to insight, "BMJ", no. 327, pp. 741-744, 2003.

Gigerenzer, G., Hoffrange, U., How to improve Bayesian reasoning without instruction: frequency formats, "Psychological Review", no. 102, pp. 684-704, 1995.

Gigerenzer, G., Mindless statistics, "The Journal of Socio-Economics", no. 33, pp. 587-606, 2004.

Golinowska, S. (ed.), Polska bieda. Kryteria. Ocena. Przeciwdzialanie [Polish Poverty: Criteria, Evaluation, Prevention]. Instytut Pracy i Spraw Socjalnych [Institute of Labour and Social Studies], Warsaw 1996.

Golinowska, S., Tarkowska, E., Topińska, I, (eds.), Ubóstwo i wykluczenie społeczne. Badania, metody $i$ wyniki [Poverty and Social Exclusion, Research, Methods and Results], Instytut Pracy i Spraw Socjalnych [Institute of Labour and Social Studies], Warsaw 2005.

Hastings, J. S., Madrian, B. C., Skimmyhorn, W. L., Financial Literacy, Financial Education and Economic Outcomes (January 13, 2014). NBER Working Paper 18412, Available at: http://www.nber.org/papers/w18612.pdf, 2012.

HM Treasury, Financial capability: The government's long term approach (December 15, 2012). HM Treasury, Norwich, Available at: http://www.oecd.org/finance/financialeducation/37965841.pdf, 2007.

Hoelzl, E., Kapteyn, A., Editorial, “Journal of Economic Psychology”, no. 32, pp. 543-545, 2011.

Iwanicz-Drozdowska, M. (ed.), Edukacja i świadomość finansowa [Financial Education and Awareness]. Wydawnictwo SGH [Warsaw School of Economics Publishing House], Warsaw 2011.

Jajuga, K., Feldman, Ł., Pietrzyk, R., Rokita, P., Integrated Risk Model in a Household Life Cycle. Wydawnictwo Uniwersytetu Wrocławskiego [Wroclaw University Press], Wrocław 2015.

Jarosz, M., (ed.), Wykluczeni. Wymiar spoleczny, materialny i etniczny [The Excluded: social, material and ethnical dimension]. Instytut Studiów Politycznych PAN [Institute of Political Studies of the Polish Academy of Sciences], Warsaw 2008.

Kempson, E. Perotti, V., Scott, K., Measuring financial capability: a new instrument and results from low and middle-income countries. Russia Trust Fund, World Bank, New York 2013.

Kochanowicz, J., Mandera, S., Marody, M., (eds.), Kulturowe aspekty transformacji ekonomicznej [Cultural Aspects of Economic Transformation]. Instytut Spraw Publicznych [Institute of Public Affairs], Warsaw 2007. 
Kochanowicz, J., Spór o teorię gospodarki chłopskiej. Gospodarstwo chłopskie w teorii ekonomii $i w$ historii gospodarczej [Dispute over the Theory of Peasant Economy. Peasant households in economic theory and history]. Wydawnictwo Uniwersytetu Warszawskiego [The University of Warsaw Press], Warsaw 1992.

Kot, S. M., Malawski, A., Węgrzecki, A., Dobrobyt społeczny, nierówności i sprawiedliwość dystrybutywna [Social Well-Being, Inequality and Distributive justice]. Wydawnictwo Akademii Ekonomicznej w Krakowie [Cracow University of Economics], Cracow 2004.

Kuchciak, I., Świeszczak, M., Świeszczak, K., Marcinkowska, M., Edukacja finansowa $i$ inkluzja bankowa $w$ realizacji koncepcji silver economy [Financial Education and Banking Inclusion in Silver Economy Approach]. Wydawnictwo Uniwersytetu Łódzkiego [University of Lodz Press], Łódź 2014.

Lusardi, A., Mitchell, O. S., Baby Boomer Retirement Security: The Role of Planning, Financial Literacy, and Housing Wealth, "Journal of Monetary Economics", no. 54, pp. 205-224, 2007.

Lusardi, A., Mitchell, O. S., Financial Literacy and Planning: Implications for Retirement Wellbeing (May 10, 2012). NBER Working Paper 17078, Available at: http://www.nber. org/papers/w17078, 2011.

Lusardi, A., American's Financial Capability (May 10, 2012). NBER Working Paper 17103, Available at: http://www.nber.org/papers/w17103, 2011.

Lusardi, A., Financial Literacy: An Essential Tool for Informed Consumer Choice? (May 10, 2012). NBER Working Paper 16084, Available at: http://www.nber.org/papers/w14084, 2008.

Lusardi, A., Schneider, D. L., Tufano, P., Financially fragile households: evidence and implications (May 10, 2012). NBER Working Paper 17072, Available at: www.nber. org/papers/17072, 2011.

Lusardi, A., Tufano, P., Debt Literacy, Financial Experiences, and Over-Indebtedness (May 10, 2012). NBER Working Paper 14808, Available at: www.nber.org/papers/14808, 2009.

Maison D., Polak $w$ świecie finansów [Poles in the World of Finance]. Wydawnictwo Naukowe PWN [Polish Scientific Publishers PWN], Warsaw 2013.

Marmot, M., Social determinants of health inequalities, "Lancet", no. 365, pp. 1099-1104, 2005.

Marody, M., Dylematy postaw politycznych i orientacji światopogladowych [Dilemmas in various political attitudes and world-views] , [in:] Wiatr, J. J. (ed.), Wartości a przemiany ładu gospodarczego i politycznego: Polska 1980-1990 [Values versus changes in economic and political governance], pp. 157-174. Wydawnictwo Uniwersytetu Warszawskiego [The University of Warsaw Press], Warsaw 1990.

McCarthy, I., Behavioural Characteristics and Financial Distress (May 10, 2012). EBC Working Paper Series:1303. Available at: http://citeseerx.ist.psu.edu/viewdoc/download? doi=10.1.1.192.2838\&rep=rep1\&type=pdf, 2011.

McKay, S., Understanding Financial Capability in Canada (May 10, 2012). Research Paper Task Force on Financial Literacy, Available at: http://financialliteracyincanada.com, 2011. 
Morduch, J., Schneider, R., The financial diaries. How American Families Cope in a World of Uncertainty. Princeton University Press, Princeton \& Oxford 2017.

Mullainathan, S., Shafir, E., Scarcity. The true cost of not having enough. Penguin books, 2014.

Nussbaum, M. C., Creating Capabilities. The Human Development Approach. Harvard University Press, Cambridge 2011.

Panek, T., Podgórski, J., Szulc, A., Ubóstwo: teoria i praktyka pomiaru [Poverty: theory and measurement]. Wydawnictwo SGH [Warsaw School of Economics Publishing House], Warsaw 1999.

Panek, T. (ed.), Statystyka społeczna [Social Statistics]. Polskie Wydawnictwo Ekonomiczne [Polish Economic Publishers], Warsaw 2007.

Panek, T., Metody pomiaru ubóstwa [Methods of Measuring Poverty], "Wiadomości Statystyczne. The Polish Statistician “, no. 7, pp. 1-12, 2005.

Panek, T., Ubóstwo i nierówności społeczne. Teoria i praktyka pomiaru [Poverty and Social Inequalities. Theory and Practice of Measurement]. Wydawnictwo SGH [Warsaw School of Economics Publishing House], Warsaw 2011.

Pechmann, C., Levine L., Loughlin, S., Leslie, F., Impulsive and Self Conscious: Adolescents Vulnerability to Advertising and Promotion, "Journal of Public Policy and Marketing", no. 24(2), pp. 202-221, 2005.

Pollack, C., Lynch, J., Health status of people undergoing foreclosure in the Philadelphia region, “American Journal of Public Health”, no. 99, pp. 1833-1839, 2009.

Ravallion, M., Growth, Inequality and Poverty: Looking Beyond Averages, "World Development", no. 29(11): pp. 1803-1815, 2001.

Ravallion, M., Income Inequality in the Developing World, "Science", no. 344, pp. 851-855, 2014.

Ray, D., Aspirations, Poverty and Economic Change, [in:] A.B. Banerjee, R. Benabou, D. Mookherjee (eds.), Understanding Poverty, pp. 409-422. Oxford University Press, Oxford 2006.

Robeyns, I., Wellbeing, Freedom and Social Justice: The Capability Approach Re-Examined. Open Book Publisher, Cambridge 2017.

Rószkiewicz, M., Objective and subjective factors shaping saving behaviours - the case of Polish households, "International Journal of Consumer Studies", no. 38, pp. 602-611, 2014.

Sen, A., Resources, Values and Development. Harvard University Press, Cambridge 1984.

Sen, A., Choice, Welfare and Measurement. Blackwell, Oxford 1982.

Sen, A., Commodities and Capabilities. Amsterdam 1985.

Sen, A., Development As Freedom. Oxford University Press, Oxford 1999.

Sen, A., On economic inequality. Oxford University Press, Oxford 1997.

Sen, A., Rationality and freedom. The Belknap Press of Harvard University Press, Cambridge-London 2002.

Shah, A. K., Mullainathan, S., Shafir, E., Some Consequence of Having Too Little, "Science", no. 338 , pp. $682-685,2012$. 
Sherraden, M. S., Building blocks of financial capability, [in:] J. M. Birkenmaier, M. J., Sherraden, S. M., Curley, J. C.,. (eds.), Financial Capability and Asset Building: Research, Education, Policy, and Practice, pp. 1-43, Oxford University Press, New York \& Oxford 2013.

Sherraden, M. S., Grinstein-Weiss, M., Creating Financial Capability in the Next Generation: An Introduction to the Special Issue, "The Journal of Consumer Affairs", no. 49(1), pp. 1-12, 2015.

Shiller, R. J., Finance and the Good Society. Princeton University Press, Princeton \& Oxford, 2012.

Świecka, B. (ed.), Wspótczesne problemy finansów osobistych [Contemporary Problems in Personal Finance Research]. Cedewu, Warsaw 2014.

Szopa, B. (ed.), Wokót zagadnień ubóstwa i bogactwa [The issues on poverty and welfare]. Uniwersytet Ekonomiczny w Krakowie [Cracow University of Economics], Cracow 2012.

Sztompka, P., Socjologia zmian społecznych [The sociology of social changes]. Wydawnictwo Znak, Cracow 2007.

Taylor, M., Measuring Financial Capability and its Determinants Using Survey Data, "Social Indicators Research", no. 102, pp. 297-314, 2011.

The World Bank, Global Financial Development Report 2014: Financial Inclusion. Washington, 2014.

Topińska, I. (ed.), Pomiar ubóstwa. Zmiany koncepcji i znaczenie [Measurement of Poverty. The Changes in the Concept and its Implications]. Instytut Pracy i Spraw Socjalnych [Institute of Labour and Social Studies], Warsaw 2008.

Topińska, I., Czynniki kulturowe w konceptualizacji ubóstwa [Cultural factors in the poverty concept], [in:] Friske W. K., (ed.), Marginalność i procesy marginalizacji [Marginality and its processes], pp. 81-87. Instytut Pracy i Spraw Socjalnych [Institute of Labour and Social Studies], Warsaw 1999.

Volkert, J., Schneider, F., The Application of the Capability Approach to High-Income OECD Countries: A Preliminary Survey (May 10, 2012). CESifo Working Paper Series No. 3364, Available at: https://www.cesifo group.de/portal/page/portal/9D6A8A 5520DB5514E04400144FAFBA7C, 2011.

Von Stumm, S., O’Creevy, M. F., Furnham, A., Financial capability, money attitudes and socioeconomic status: risks for experiencing adverse financial events, "Personality and Individual Differences", no. 54, pp. 344-349, 2013.

Wilkin, J., (ed.), Wielofunkcyjność rolnictwa. Kierunki badań, podstawy metodologiczne i implikacje praktyczne [Multifunctional agriculture. Research Directions, methodologycal foundations and practical implications]. Instytut Rozwoju Wsi i Rolnictwa PAN [Institute of Rural and Agricultural Development of the Polish Academy of Sciences], Warsaw 2010.

Wolff, J. De-Shalit, A., Disadvantage. Oxford University Press, Oxford 2007.

Xiao, J., Chen, C., Chen, F., Consumer financial capability and financial satisfaction. "Social Indicators Research", no. 118, pp. 415-432, 2014. 
Xiao, J., Chen, C., Sun, L., Age differences in consumer financial capability. "International Journal of Consumer Studies", no. 39, pp. 387-395, 2015.

Xiao, J., O'Neill, B., Consumer financial education and financial capability. "International Journal of Consumer Studies", no. 40, pp. 712-721, 2016.

Zdanowska, M., Financial capability - zdolność zarządzania finansami osobistymi [Financial capability - abilities to manage personal finance], Zeszyty Naukowe Uniwersytetu Szczecińskiego no. 680, „Problemy Zarządzania, Finansów i Marketingu” no. 21, pp. 251-260, 2012.

Received: March 2017, revised: March 2018 